\title{
İç Göç ve Mekânsal Dışlanma
}

Internal Migration and Spatial Exclusion

\section{Doç. Dr. Çağla Ünlütürk Ulutaş - Arş. Grv. Asiye Kamber}

Başvuru Tarihi: 10.03 .2016

Kabul Tarihi: 21.09.2016

\section{Öz}

1980'li yıllardan itibaren hızh bir ekonomik gelişim sergileyen ve küresel piyasalarla eklemlenen Denizli, söz konusu gelişmelere paralel olarak önemli bir iç göç merkezine dönüşmüştür. Göçmen nüfus, yerli nüfustan mekânsal olarak da ayrışmış, çoğunlukla kent çeperinde sanayi merkezlerine yakın çöküntü alanlarma yerleşmişlerdir. Bu çalışmada göç ve mekânsal dışlanma ilişkisini ortaya koymak amacıyla, en yüksek göç hızına sahip onuncu il olan Denizlideki beş ayrı göçmen yerleşiminde katılımo olmayan gözlemler ve bu mahallelerde yaşayan 40 katılımcıyla yarı yapılandırılmış yüz yüze görüşmeler gerçekleştirilmiştir. Araştırma sonucunda Denizlide, göçün erken aşamalarında göç edenlerin toplumsal uyum ve entegrasyon olanaklarına kavuşmuşken, 1990’l yıllardan sonra göç edenlerin sosyal dişlanma ile yüz yüze kaldıkları bulgulanmıştır. Katılımcıların yaşadıkları mekanla kurdukları ilişkiler incelendiğinde, mesafe yakınlığına karşın kent merkezindeki alışveriş ve eğlence olanaklarından sıkça yararlanmadıkları, mekânsal damgalanmaya maruz kaldıkları ve mekânsal dışlanma nedeniyle kent hizmetlerine eşit biçimde erişemedikleri görülmüştür.

Anahtar Kelimeler: İç Göç, Sosyal Dışlanma, Mekânsal Dışlanma, Denizli

\begin{abstract}
Denizli, which has clearly exhibited rapid economic development since 1980s, has become an important internal migration center. However, the immigrant population is spatially segregated from the local population and is mostly settled in the peripheral areas of the city nearby the industrial centers. In this study, in order to reveal the relationship between migration and spatial exclusion, besides non-participant observations, semistructured face to face interviews with 40 participants was conducted in five migrant settlements in Denizli. It has been found that although immigrants in the early stage, have a chance to access the possibilities of social cohesion and integration, since 1990s, immigrants have been facing social exclusion. Considering their relationships with the space, it is seen that, they don't often benefit from the shopping and entertainment facilities in the center, they are exposed to spatial stigmatization and spatial exclusion.
\end{abstract}

Keywords: Internal Migration, Social Exclusion, Spatial Exclusion, Denizli

Doç. Dr. Çağla Ünlütürk Ulutaş, Pamukkale Üniversitesi İİBF, caglau@gmail.com Arş. Grv. Asiye Kamber, Marmara Üniversitesi Sosyal Bilimler Enstitüsü, asiyekamber@hotmail.com 


\section{Giriş}

Göç tanımlarında çeşitli farklılıklar bulunsa da en basit haliyle göç denildiğinde bir mekandan başka bir mekana yapılan hareket ve süreci algilıyoruz. Genel olarak bu kavram bazı sosyal, ekonomik, siyasi ve kültürel öğeleri de içermektedir. Yalçın (2004) göçü "ekonomi, siyasi, ekolojik, bireysel nedenlerle bir yerden başka bir yere yapılan ve kısa, orta, uzun vadeli, geriye dönüş veya sürekli yerleşim hedefi güden coğrafik, toplumsal ve kültürel bir yer değiştirme" olarak tanımlar. Bu yer değiştirme süreci ulus devlet sinırlarında gerçekleştiğinde "iç göç" olarak adlandırılmaktadır. Burada iç göç tanımımıza ilişkin vurgulamamız gereken husus, iç göçün kişilerin kendi isteğiyle, ekonomik veya sosyal şartlardan ötürü veya zorunlu (doğal afetler, savaş ve diğer güvenlik tehdidi gerekçelerine bağlı) olarak gerçekleşebileceğidir. Gelişmekte olan ülkelerin birçoğunda, kırdan kente göç, sosyal dışlanmanın başlica gerekçelerinden birini oluşturmaktadır. Çoğunlukla kırsal alanda yaşanan mülkiyetten dışlanma sonucunda kentlere itilen göçmenler, kentsel yaşamda çok boyutlu dışlanma sorunluyla karşı karşıya kalabilmektedirler. Bu durum, sosyal dışlanmanın mekânsal olarak yer değiştirmesi biçiminde ifade edilebilir (Sapancall, 2003, s.104).

Denizli, 1980'li yıllardan itibaren Türkiye ekonomisindeki ve sanayi üretimindeki payındaki artışa paralel olarak önemli bir göç merkezi haline dönüşmüştür. Göçün kaynağı Denizli’ye bağlı ilçe ve köylerden, Afyon, Manisa, Burdur, Aydın, Uşak ve İzmir gibi çevredeki illerin kent merkezleri ve köylerini, bunların yanı sıra Ağrı, Erzurum, Konya, Muş gibi orta ve Doğu Anadolu illerinin kent merkezleri ve köylerini içeren bir çeşitlilik arz eder. Net göç hızı 2001 ve 2008 ekonomik krizleri ile dönemsel olarak yavaşlamış, 2011 yllında binde $-0,4^{1}$ düzeyinde gerçekleşerek aldığı ve verdiği göç dengelenme eğilimine girmiştir. 2015 yılı itibariyle yeniden binde 5,3 düzeyine yükselmiştir. Halen Türkiyéde en yüksek göç hızına sahip onuncu ildir ve göçmen nüfusu yüksek bir kent olma özelliğini sürdürmektedir. Göçün yarattığ sosyal sorunlara çözüm bulamamışken, geçmişten aktarılan çevresel, sosyal ve ekonomik sorunlar, Denizli toplumsal yaşamının dengesini özellikle göçmenler aleyhine bozarak, yeni toplumsal risk alanları yaratmıştır (Güzel, 2013, s.2). Göçmenler,

1 TÜİK, İllerin aldığı, verdiği göç, net göç ve net göç hızı, 19802015, http://www.tuik.gov.tr/VeriBilgi.do?alt_id=1067 genellikle kentin kiyısında yer alan ve organize sanayi bölgesine yakın bir yerde konumlanmış bulunan Sümer, Sevindik, Karşıyaka, Gümüşler bölgelerinde yoğunlaşmaktadırlar. Yerli ve göçmen nüfus arasında ortaya çıkan mekânsal ayrışma, göçmenlerin kendi arasında hemşeriliğe dayalı ikincil bir ayrışmayı doğurmaktadır. Bu çalışmada, Denizli ilinin Gümüşler, İlbade, Karşıyaka, Alparslan ve Esentepe Mahallelerindeki göçmen nüfusla gerçekleştirilmiş olan nitel araştırmanın sonuçları paylaşılacaktır. Araştırmanın temel sorunsalı Denizli’ye iç göç yoluyla yerleşen göçmenlerin mekânsal yerleşimlerinin dışlanmaya yol açıp açmadığıdır. Bu sorunsal etrafinda üç araştırma sorusu geliştirilmiştir: İlki göçmenlerin kent çeperindeki belli mekanlarda yığışmaları, toplum tarafından dışlanmalarına, suç potansiyeli, gelir düzeyi veya siyasi eğilimlerine ilişkin olarak damgalanmalarına neden olmakta mıdır? İkincisi, göçmenlerin yaşadıkları mekanlarda erişebildikleri kamusal hizmetler, niteliksel ve niceliksel olarak yerli nüfusun erișebildiği kamusal hizmetlerden farklılaşmakta mıdır? Üçüncüsü, göçmenlerin mekânsal dışlanma ve damgalanmaya ilişkin algıları ve refah düzeyleri göç tarihine göre farklılaşmakta mıdır? Bu eksende, birinci bölümde Türkiye'deki göç tarihine kısaca değinilmesinin ardından, çalışmanın odaklandığ 1 mekânsal dışlanmanın kavramsal çerçevesi çizilecektir. Daha sonra alan araştırmasına konu olan Denizli kentinin göçle ilişkisi ele alınacaktır. Son bölümde ise söz konusu araştırma soruları etrafında kurgulanan saha araştırmasının bulguları değerlendirilecektir.

\section{Türkiye'de İç Göçün Tarihsel Gelişim Süreci}

İçduygu ve Sirkeci (1998) iç göç tarihini, süreç, yoğunluk ve biçimsel farklılaşma bakımından- dört döneme ayırırlar: 1923 den 1950'ye, 1950'ler ve 60'lar, 60'lar, 70'ler ve 80'ler ve 1980 sonrasi. 1950'lere kadar olan dönem, kentli nüfusun 27-50 arasında yalnızca \%3 arttığı, iç göçün cılız olduğu dönemdir. $\mathrm{Bu}$ dönemde göçler daha çok emek göçleri ve Ege, Marmara ve Akdeniz Bölgelerinin ovalık kesimleri ile dağlık kesimleri arasında mevsimlik göç şeklinde gerçekleşmiştir. Bu dönemde köyün modernizasyonu, Zonguldak'ta olduğu gibi yeni açılan madenlerde çalıştırılmak üzere geniş kitlelerin topraktan koparılıp işçi haline dönüştürülmesi, kuraklık, heyelan veya deprem sonucu ortaya çıkan zorunlu göçler ve 1934 
İskân Kanunu ile birlikte bazı grupların iskânı gibi demografik hareketlilikler, dönemin iç göç haritasını belirlemekte etkilemiş ve bu dönemde köyden kente net iç göç yalnızca 214.000 dolayında gerçekleşmiştir (Kaya, 2012, s.38)

Göç tarihine baktığımızda Türkiye’de ilk ciddi göç hareketlerinin 1950 'li yıllar itibariyle gerçekleştiğini söyleyebiliriz. İlk sıçrama, 1950-55 döneminde, Türkiye'nin Marshall Planı'ndan yararlanmasına olanak verilmesi üzerine tarımda hızlı bir makineleşmenin yaşanmasıyla ortaya çıkan tarımsal dönüşümle gerçekleşmiştir. Göçe ivme veren etkenler arasında nüfus artışı, tarımdaki düşük üretkenlik ve kırsal alanlardaki artan işsizlik ve eğitim nedeniyle kentlere yönelme de önemlidir. Tarımda modernleşmeye yönelik bir iktisat politikası yürüten Demokrat Parti iktidarı, önceki dönemin aksine nüfusu kırda tutmaya çalışmamıştır. Sanayinin gelişmediği ulusal pazarların yeni yeni kurulduğu 1950-60 yılları arasında büyük kentlere göçle, kapitalist ekonominin kentte yerleşmesi sağlanmıștır. Kente gelen göçmen nüfus gecekondularda barınmaya başlamıştır. Göçmen kadınlar çoğunlukla tarımsal niteliklerini kentsel işgücü piyasasına taşıyamamış, erkek nüfus yedek işgücü ordusunu oluşturarak ücretlerin yükselmesini engellemiş ve sanayinin gelişmesine katkıda bulunmuşlardır. Ayrıca, tarımda önemli bir gelir artışı sağlayan büyük toprak sahipleri de büyük kentlere göç ederek yatırımlarını sanayi ağırlıklı işlerde yoğunlaştırmışlardır (Özbay ve Yücel, 2001, s.11). Böylece cumhuriyetin ilk 30 yilında \%25 düzeyinde seyreden kentsel nüfus oranı, 1960'lara gelindiğinde \%38'e yükselmiştir. 1960-1970 aralığında ise, önceki dönemde söz konusu olan itme çekme faktörlerine yeni kurulmuş göçmen ağları, kentsel altyapı hizmetlerindeki gelişim ve daha iyi eğitim ve sağlık olanakları da eklenmiştir. Böylece 1970 'lerin sonunda kentsel nüfus oranı \%44'e kadar yükselmiştir (Berker, 2011, s. 202).

1960 ve 1980 arası dönem iç göçün giderek arttığı ve köyden kente göçten ziyade kentten kente göçün yoğunlaştığı bir süreç olarak tanımlanmaktadır. Bu dönem hızla göç alan kentlerde konut ve işsizlik sorununun belirdiği dönemdir. Gecekondulaşma olgusu bu dönemlerde ortaya çımış, kentlere göç edenler yaşamlarını sürdürmek ve geçinmek için kentlerin ücra yerlerine gecekondular inşa etmiş ve çarpık kentleşme olgusu meydana gelmiştir. Gecekondu düşük gelirli istihdam alanlarında çalışan ve sosyokültürel farklılıklardan dolayı kente uyum göstermekte zorlanan bir nüfusun, mülkiyeti başkalarına ait topraklar üzerine yasal olmayan yollardan yapılmış konutlara yerleşmesiyle ortaya çıkmış bir olgudur (Tekşen, 2003, s.45). Bu olguyu artıran nedenlerden biri de, iç göçle çı̆̆ gibi büyüyen yeni yerleşme düzeni sorununun çözümünün yerel yönetimlerin imkânlarına terk edilmesidir. Bu durumda yerel yönetimler de hızlı bir tempoyla kentlerine gelen kırsal nüfusun yerleşme gereksinimlerini karşılayamamış ve göçen nüfus kendi imkânlarıyla bu sorunu çözümlediğinde de sonuç, kamu elindeki arazilerin bir gecede inşa edilen gecekondularla kullanılması olmuştur (Erdem, 1986:188). Bununla birlikte gerçek olan bir şey varsa o da gecekondu olgusunun çok boyutlu bir sorun olduğudur. Gecekondulaşma, iktisadi, sosyal ve kültürel bir dizi uyumsuzlukları ve sorunları bünyesinde barındırmaktadır. Gecekondu, kentin kenar semtlerinde izinsiz olarak bir gecede kuruluverilen fakat sosyal ve ekonomik bakımdan kent hayatına (merkezine) bağlı bir yerleşme șeklidir. 1950'lerden sonra hızlı kentleşmeye paralel olarak "gecekondulaşma" sorunu ortaya çıkmış ve sosyal yapı bakımından çözülmesi zorlaşan ağır problemlere yol açmıştır. Keza, gecekondular zamanla rant alanlarına dönüşmüş ve bazı kesimlerin daha da yoksullaşmasına neden olurken, bazı kesimlerin zenginliğini daha da katlamıştır (Işık ve Pınarcioğlu, 2003, s.155).

İlk dönem gecekonduları, piyasada satılmak amacıyla değil, kente göç eden birinci kuşağın barınma gereksinimlerine yanıt vermek amacıyla üretilmiştir. 1970)li yıllarda' itibaren ortaya çıkan ikinci kuşak gecekondular, hazine arazilerinin yanı sıra, sahipleri tarafından gecekondu yapımı amaciyla parsellenip satılan kent çeperindeki arsaların üzerine kondurulmaya başlanmıştır. Bu süreçte yapımcı ve konut sahibi özdeşliği ortadan kalkmış ve gecekondular metalaşmıştır. 1980'li yıllara gelindiğinde konut sahibi- kullanıcı özdeşliği de ortadan kalkmaya başlamış ve gecekondu alanlarında kiracılık artmıştır (Işık, 1996: 44). Böylece gecekondulardaki yoksulluğun sürekli hale dönüşmesi ve birinci kuşak göçmenlerden ikinci kuşağa, ikinci kuşak göçmenlerden üçüncü kuşağa aktarılmaya başlanması ise "nöbetleşe yoksulluğu" gündeme getirmiştir. Nöbetleşe yoksulluk, esas olarak kente önceden gelmiş göçmen grupları ile kentte imtiyazlı konumda bulunan bazı grupların, kente daha sonradan gelen kesimler ile diğer imtiyazsız gruplar üzerinden zenginleşmeleri, bir anlamda yoksulluklarını 
bu gruplara devredebilmeleri sonucunu doğuran bir ilişkiler ağıdır (Işık ve Pınarcıoğlu, 2003, s.155). Öte yandan, kentsel yoksulluk, toplumun istihdam olanakları açısından örgütsüz marjinal kesimleriyle (işin süreksizliği ve güvensiz oluşu dolayısıyla en düşük gelir getirisi olması itibariyle) gecekondu toplumunda örtüşmektedir. Kentlerde sosyokültürel özellikler açısından merkez çevre ya da modern ve geleneksel ayrımında mekanlar yaratılmakla birlikte buralardaki yaşantı karşılıklı bağımlılık ilişkisi içinde eş zamanlı ve eş mekanlı olabilmektedirler (Tekeli, 1976, s.15).

1980-2000 arası iç göçler incelendiğinde, kentten kente göçün iller arasında gerçekleşen nüfus hareketliliğinin en önemli türü olduğu ve iç göç hareketlerinin Doğu, Güneydoğu ve Karadeniz gibi az gelişmiş bölgelerden Marmara ve Ege gibi gelişmiş bölgelere doğru yöneldiği görülmektedir (Kalkınma Bakanlığı, 2014, s. 27) Bu dönemde gelişen iletişim ve ulaşım olanakları, nüfus hareketliliğinin önündeki tüm engelleri kaldırmıștır. Dönemin sonunda kentsel nüfus oranı $\% 65$ 'e erișmiștir. Bu dönemde piyasa yönelimli politikalara odaklanılması, özelleştirmeler, yabancı sermaye yatırımlarının özendirilmesine dönük kurumsal düzenlemeler ve ihracata dayalı büyüme stratejilerine geçiş işgücü piyasası açısından da önemli dönüşümler gerçekleşmesine yol açmıştır (Berker, 2011, s. 203). Ücretler genel düzeyindeki düşüş, sendikalarda zayıflama, işten çıkarmalar ve iş yoğunlaşmasında artış, taşeronlaşma, eve iş verme gibi dönüşümler işgücü piyasasının kente gelen işgücünü emme kapasitesini göreli olarak düşürmüştür. Öte yandan bu dönemde Güney Doğu ve Doğu Anadolu'daki sosyo-ekonomik sorunlar ve yeni tarım politikaları ile küçük köylülüğün çözülmesindeki hızlanma gibi itici faktörler ortaya çımıştır. Bu dönemde göç eden kuşak, işsizlik, kayıt dışılık ve kentsel yoksulluk sorunuyla daha çok karşı karşıya kalmış, göçmenlerin karşı karşıya kaldığı ekonomik yetersizlikler çarpık kentleşmenin yanı sıra suça bulaşma, sokak çocukları gibi yeni sosyal sorun alanları doğurmuştur (Kaygalak, 2001; Buğra, 2008).

1990'ların 2. Yarısından sonraki dönem göç literatüründe "zorunlu göç" olgusunun belirdiği dönemdir. Terör, mezhep çatışmaları ve köy boşaltmalar nedeniyle can ve mal güvenliği olmayan pek çok kişi bu dönemde Doğu ve Güneydoğu Anadolu bölgelerinin kırsal alanlarından bu bölgelerin kent merkezleri ile batıdaki büyük kentlere doğru göç etmek zorunda kalmıştır. Bu hareket daha önceki göçler gibi ekonomik kökenli değil siyasal kökenlidir. Şüphesiz bu sürecin toplumsal ve bireysel boyutlarda pek çok olumsuz sonucu olmuştur. Göçmenlerin yaşadıkları kültürel dışlanma, ötekileştirilme ve iş gücü piyasasından dışlanma bu sorunlardan bazılarıdır. Bu sonradan oluşan zorunlu ve yeni göç halkası gecekondulaşma bölgelerinde yedek işgücünün, kayıt dışı istihdamın ve dışlanmışlı̆̆ın yeni bir yüzünü oluşturmuştur ve yoksulluğu bir önceki göçmen kuşağından devralıp "nöbetleşerek" kent yaşamında yerini almıştır (İçduygu ve Sirkeci, 1998, Iş̧k ve Pınarcıoğlu, 2003, Kaya, 2009).

\section{Mekânsal Dışlanma}

Mekansal dışlanma, sosyal dışlanmanın bir biçimi olarak karşımıza çıkmaktadır. Çok boyutlu bir kavram olan sosyal dışlanma çoğu kez bu farklı boyutlarla iç içe olan dinamik bir süreci içermektedir. Bu içe içe geçmişlik ekonomik, kültürel ve siyasal alanlarda dışlanma sarmalını oluşturmaktadır. Literatürde çoğu kez ekonomik temeller ve yoksullukla anılan bu olgu, günümüzde gittikçe daha da belirginleşmektedir ve dışlanmayla en çok yüz yüze kalan gruplardan biri göçmenlerdir.

Marshall (1999, s. 150)'a göre sosyal dışlanma, bireylerin ya da hanelerin kaynaklardan ya da toplumla sosyal bağlar kurmaktan yoksun bırakılması sürecini ifade eder. İlk olarak 1960'larda Fransa'da kullanılmaya başlanan sosyal dışlanma kavramı, 1980'li yılların ekonomik krizi ve yeniden yapılanma sürecinde, refah devletinin krize girmesiyle daha sık kullanılmaya başlanmıştır. Fransa'da sosyal dışlanma kavramını literatüre kazandıran Rene Lenoir, sosyal dışlanmışları devlet tarafından uygulanan refah programlarına erişim olanakları olmayanlar olarak tanımlamıştır (Zohir vd., 2008).

Sosyal dışlanma, sosyal entegrasyonu sağlayan karar mekanizmalarına, kaynaklara ve ortak anlatılara erișimden dıșlanmadır. Söz konusu olanaklara erișimin kabul ya da reddedilme biçimlerinin çok sayıda mekânsal tezahürü bulunmaktadır. Sosyal olanaklar sınırlandırıldığı ölçüde mekânsal olanaklar da sınırlandırılmakta (ya da tam tersi), geniş sosyal olanaklara sahip kişi ve gruplar gezmek, yaşamak ve çalışmak için mekânsal bir çeşitliliğe de sahip olmaktadır (Madanipour, 2016, s. 208). Çok sayıda kentte, hali 
vakti yerinde kesimlerin korunaklı konut alanlarında yoğunlaşmaları bir tercih, kent yoksullarının kent çeperinde ikamet etmeleri ise bir zorunluluktur. Kentsel mekanının hiyerarşik biçimde katmanlaşması ve sosyo-mekansal dışlanma sosyo-ekonomik ayrımları yeniden üreten bir mekânsal adaletsizlik yaratmaktadır (Dikeç 2001). Söz konusu koşullarda kentsel mekan, ayrıcalıklılarla ötekilerin arasındaki mücadelenin mahali haline gelir (Cook, 2015, s. 42).

Mekânsal dışlanma "bir dizi nedenden dolayı belli mekanlara ulaşımda ve mekandan yararlanmada sorunların bulunması, engellerle karşılaşılması durumudur." Mekânsal dışlanmanın iki temel veçhesinden söz edilebilir. İlki, toplum genelinin kişiyi yaşadığı mekanı/coğrafyası nedeniyle dışlaması, suç potansiyeli, gelir düzeyi, etnik köken, politik eğilimler gibi gerekçelere dayalı olarak damgalaması, ayrımcılığa tabi tutmasıdır. İkincisi, kişinin yaşadığ 1 mekandaki kamusal hizmetlerin nitelik ve niceliksel seviyeleri nedeniyle toplumsal hayatın içine tam anlamıyla entegre olamamasıdır. Öte yandan dışlanmışların ortasında yaşamak sosyal mesafeleri derinleştirmekte ve sosyal dışlanma kısır döngüsünü kırmayı zorlaștırmaktadır. Her ne kadar söz konusu mekanlar, sakinlerine ucuz kira ve hemşerilik ağları gibi bazı avantajlar sunsa da, yaşayanları dibe çekmek gibi yadsınamaz bir etkisi de mevcuttur (Adaman ve Keyder, 2006, s.10-36). Göç sürecinin ev sahibi toplumda kıt kaynakları düzenleme, bölüşüm ve yeniden dağıtım, eğitim gibi kamu hizmetlerinin sunulmasını içeren kapsamlı sonuçları vardır. Bu boyut özellikle göçmenlerin ev sahibi toplum ile kaynaşmasında ya da bu düzenlemelerin gerçekleştirilmediği koşullarda sosyal dişlanma sorununun ortaya çımasında etkin rol oynamaktadır (Güzel, 2013, s.10). Barınma ve kişinin kendini güvende hissetme ihtiyacı en temel ihtiyaçlardan birisidir, ancak yoksulluk ve göçle iç içe ortaya çıkan durumda çoğunlukla göçmenler barınmayla ilgili sıkıntılar yaşamaktadır. Göçmenlerin kentin çöküntü alanlarında bir kenara itilmiş, bulundukları mekan yüzünden dışlanmış olmaları, temel refah hizmetlerine ve işgücü piyasasına erişim sorunlarından, kentlerin mutena semtlerine sağlanan belediyecilik ve altyapı hizmetlerine ulaşmamalarına kadar çok sayıda sorun alanını beraberinde getirmektedir. Bu noktada sosyo-mekansal dışlanma kentsel vatandaşlıkla ve kentsel mekana erişim ve kent merkezinin firsatlarını kullanabilme pratikleriyle sıkı bir ilişki içindedir (Cook, 2015, s. 6).

\section{Küresel Fabrika Kenti Denizli ve İç Göç}

Denizli’de iç göç, Türkiye'de iç göçün tarihsel seyrine benzer bir seyir izlemiştir. 1960'lı yıllarda Denizli ve çevresindeki illerin kırsal bölgelerinden kent merkezine yönelen göçlerle başlayan iç göç serüveni, 1990’larda bir küresel fabrika kentine dönüşmesiyle yeni bir evreye girmiştir.

1950'li yıllarda Denizli karayoluyla İzmire bağlanmış, 1958'de elektrik kullanımının yaygınlaşması, küçük sanayiyi canlandırmaya başlamıştır 1960'larda 1. ve 2 . Sanayi sitelerini tamamlayarak büyük sanayi alt yapısını hazırlamıştır. 1960'ların sonunda tüm Türkiyeye karayolu bağlantısı sağlanmış olan Denizli’nin bu yıllardaki merkez nüfusu 70000 kadardır. Bu dönemde Denizli kırsalından ve Afyon, Burdur gibi komşu illerin köy ve kasabalarından kent merkezine göçler hızlanmaya başlamıştır. 1970'li yıllardan itibaren Denizli imalat sanayii özellikle dokuma ve metal sektörleri, hızla gelişmeye başlamıştır. 1973 yılında "Kalkınmada Öncelikli İller" kapsamına alınan Denizli, aynı dönemde yurtdışında çalışan işçilerin oluşturdukları sermayeler ile oluşturdukları çok sayıda şirkete mekan olmuştur. 1980'li yıllardan itibaren firmaların ölçekleri büyümeye başlamış, 1990'lara gelindiğinde tekstil firmalarının küresel pazara açılmasıyla sınai patlama gerçekleşmiştir (Bilgen vd.,2009). Böylece Denizli, Anadolu kaplanları gibi kimi tanımlamalar altında yeni yerel kalkınma ve sanayi odaklarından biri haline gelmiştir (Karaçay Çakmak ve Erden, 2005, s.112). Denizli’de başını tekstil sektörünün çektiği çok sayıda fabrikanın küresel üretim ve ticaret sisteminin bir halkası haline gelmesiyle birlikte, kent çok sayıda işçinin kitlesel hareketliliğine de sahne olmuştur. Tekstil ve diğer sanayi kollarındaki atılımlarının yanı sıra, Denizli'de çimento ve il içinden ve dışından Denizli kent merkezine yönelen göçleri hızlandırmış ve kenti yatay olarak büyütmüştür (Kara, 2010: 109). Pek çok kentin hızlı sanayileşme sürecinde karşılaştığ 1 gibi yeni açılan sanayi alanlarının beraberinde getirdiği alt yapı olanakları, sanayi alanlarının çevrelerinin gecekondu alanları ile kuşatılması sonucunda yağ lekesi şeklinde bir hızlı büyüme ile karşı karşıya kalmıştır (Akın, 2012).

Göç sonucunda yeni mahallelerin oluşumunda hemşerilik ilişkileri başat rol oynamıştır. Örneğin Ankara yolu üzerindeki Dokuzkavaklar, Kirişhane, Anafartalar, Sümer ve Sevindik mahalleleri çoğunlukla Çal, Çivril, Baklan ve Afyon'un ilçelerinden göç edenle- 
rin yoğunlaştığı yerleşim yerleri olurken, Antalya yolu üzerindeki Yenimahalle Cumhuriyet ve Fatih mahalleleri Acıpayam, Tavas, Çameliden gelenlere ev sahibi olmuştur. Doğu ve Güneydoğu'dan göç edenler daha çok Karşıyaka ve özellikle de Esentepe Mahallesi’ne yerleşmişlerdir (Bilgen vd.,2009: 60). Doğudan yönelen göçün kaynağının özellikle Ağrı, Siirt ve Muş kentlerinden olduğu görülmektedir. A $\breve{g}-$ rilıların Denizli’ye göçü genellikle 1970'lerde ekonomik sebeplerle başlamışken Siirt ve Muşluların göçü 1990 'larda güvenliğe dayalı ve siyasi sebeplerden dolayı olmuştur. Bunların dışında Erzurum, Batman, Diyarbakır ve Van'dan gelen göçmenler de bulunmaktadır (Uslu, 2012, s. 94).

1975-80 arasında verdiği göç aldığı göçten fazla olan Denizli'de (net göç hızı binde -5), 1980'lerden itibaren sınai gelişimin sonucunda başka kentlerden göç almaya başlaması ile, 1980-85 arasında göç hızının 3,5 olarak gerçekleştiği görülmektedir. 1985-1990 arasında \%15,4'lük göç hızına sahip olan ile yönelen göç 1990 sonrası daha da hızlanarak \% 19,9'a yükselmiştir. 2001 krizinin kent ekonomisine etkisi çok olumsuz olmuş ve göç vermeye başlamıştır. Aynı biçimde 2008 kriziyle yaşanan talep daralmasıyla il, net göç veren iller arasında yer almaya başlamıştır. 2012 yllında ise tekrar göç alan bir il konumuna gelmiştir.2015 yılında bu durum devam ederken net göç hızı 5,3 olarak gerçekleşmiştir².

1980'lerin ikinci yarısından itibaren gecekondu alanlarından yüksek rant beklentisi, gecekondu alanlarının kent merkezi ile bütünleşmesini sağlayan bir rol oynamıştır. Ancak 1990'larda bu strateji tükenirken, gecekondu alanlarındaki radikalleşme ve kenti $\mathrm{d}_{1}$ şarıdan izleyen gecekondu nüfusu dikkat çekmeye başlamıştır. Göçün çekim merkezi olan pek çok kentte, kimlik farklılıkları ekseninde bir kopuş ve içe kapalı cemaatleşme eğilimleri dikkat çekmiştir. Ancak 1990'lı yıllar iç göçün çekim merkezi olan diğer metropol kentlerden farklı olarak Denizli'nin küresel tekstil ağının yeni ve önemli bir bileşeni haline geldiği yıllardır. Bu durum, göçmenlerin işgücü piyasası tarafından emilmesini sağladığı gibi, aynı zamanda, kente, sakinlerini bir arada tutabilme gücü vermiştir. Kentteki hızlı ekonomik gelişim, gerek yerli gerek

2 İllerin aldığı, verdiği göç, net göç ve net göç hızı, 1980-2015 istatistikleri için bkz. http://www.tuik.gov.tr/PreIstatistikTablo. do?istab_id=1595 göçmen nüfusa daha önce hayal bile edemeyecekleri yukarı hareketlilik olanakları sunmuştur (Işık, 1996, s.46-47). Ne var ki Denizli'deki bu kentsel bütünleşme süreci, ekonomik krizlerin ve kentin tekstil sektöründeki başat rolünü kaybetmesinin de etkisiyle gevşemiştir.

Dünyada liberal ekonomi politikalarının uygulamalarını arttırmak ve daha küresel ve rekabetçi bir dünya hedefiyle, 1 Ocak 1995'de Dünya Ticaret Örgütünün (DTÖ) kurulmasıyla GATT kapsamında bulunan MFA yerini “Tekstil ve Hazır Giyim Anlaşması'na (ATC) bırakmıştır. Türkiye’nin üyesi bulunduğu DTÖ'ye 2002 yılında Çin üye olmuş, 1.1.2005 yllından itibaren tekstil ve hazır giyim sektöründe tüm kotalar sıfırlanmıştır. Ancak bu karar Türkiye açısından ciddi iç ve dış pazar kayıplarına ve cari açıklara yol açmıştır (Atılgan ve Şen, 2006, s. 220). Bir başka olumsuz etki ise reel ücret seviyelerindeki düşüş olmuştur. Türkiye ve Çin arasında süregiden tekstil rekabetinde, Türkiye'nin en dezavantajlı konumda olduğu kriter üretim maliyetlerilerdir. Bu durum ülkemizde işgücü maliyetlerini düşürmeye yönelik kimi yönelimlere neden olmuştur (Mangır ve Ay, 2009, s. 187). Çin'le rekabetin yol açtığ sosyal damping ve ardından gelen 2008 krizi, Denizli’nin göçmen işgücü için refah olanakları yaratan bir kent olma özelliğini yitirmesine yol açmıştır.

Torlak ve Polat (2006) tarafından Denizli’nin yerli nüfusunun yoğunlaştığ Çaybaşı Mahallesi ile göçmen nüfusunun yoğunlaştığı Sevindik Mahallesi sakinleri arasında yapılan karşılaştırmalı çalışma, kentlileşme olgusuna odaklanırken göçmenlerin maruz kaldığ sosyal dışlanmayı da gözler önüne sermektedir. Söz konusu çalı̧̧ma, eğitim düzeyi, gelir seviyesi, sosyal koruma, konut sahipliği açısından her iki yerleşim yerinde büyük farklılıklar olduğunu ortaya koymuştur. Çaybaşı Mahallesi'ndeki katılımcıların \%34,7'si, Sevindik Mahallesindekilerin ise yalnızca 9,5'i üniversite mezunudur. İlkokul mezunlarının oranı Çaybaşı'nda \%23,2'yken, Sevindik’te \%63,2'dir. Çaybaşı mahallesinde yaşayanların yalnızca \%2'si $250 \mathrm{TL}$ altında gelire sahipken bu oran Sevindik'te \%24’tür. Çaybaşı̀nda sosyal koruma kapsamında olmayanların oranı yalnızca \%3 iken, bu oran Sevindik'te \%16, 5’tir. Çaybaşı Mahallesi sakinlerinin \%35’i, Sevindik Mahallesi sakinlerinin \% 46’sı kiracıdır. 


\section{Denizli'de Göçmenlere Yönelik Bir Alan Araştırması}

\section{Araştırmanın Amacı ve Yöntemi}

Araştırmanın amacı Denizli’nin yoğun göç alan Gümüşler, Karşıyaka, Sevindik ve İlbade bölgelerine göç eden kişilerin kentsel mekanla kurdukları ilişkinin keşfedilmesi ve ikamet mekanlarının kentsel hizmetlere erişim, ayrımcilık, sosyal dişlanma ve mekânsal damgalanma gibi etkilerinin olup olmadığının irdelenmesidir. Bu amaca yönelik olarak Denizli ilinde Gümüşler, Esentepe, Alparslan, İlbade ve Karşıyaka Mahallelerinde yaşayan 40 göçmen ile yarı yapılandırılmış yüz yüze görüşme gerçekleştirilmiştir. Katılımcılara muhtarlar, mahalle bakkalları, kahvehaneler aracılığıyla veya kapı önlerinde ulaşımıştır. 7 kişi görüşmeyi kabul etmemiştir. Görüşme ve gözlemler toplamda üç haftada tamamlanmıştır. Araştırmaya katılan göçmenler göç ettikleri kaynak mekan (Denizli’nin ilçeleri, civar köyler, çevre iller, Doğu ve Güneydoğu illeri), cinsiyet, yaş ve göç tarihi açısından çeşitlilik göstermektedir. Katılımcıların 27'si erkek, 13'ü kadındır ve yaşları 19-40 arlığında yoğunlaşmaktadır. Yalnızca 2 erkek katılımcı 50 yaş üzerinde ve 2 erkek katılımcı da 16 yaşında lise öğrencisidir. Katılımcıların yüksek bölümünü erkeklerin oluşturması araştırma kısıtlarından biridir. Görüşme amacıyla evlere girmek gerek araştırmacıların güvenliği gerekse katılımcıların güveni açısından mümkün olmadığından yalnızca sokakta bulunan, kapı önünde veya kahvehanede oturmakta olan veya alışveriş yapmakta olanlardan görüşmeyi kabul edenlere erişilebilmiştir. Ayrıca adı geçen mahallelerde yaşam tarzı, altyapı hizmetleri, insanlar arası ilişkiler üzerine odaklanan katılımcı olmayan gözlem gerçekleştirilmiştir. Çalışmada yalnızca alt gelir grubundaki göçmenlerin yaşadığı mahallelere odaklanılmıştır. Beyaz yakalı işgücünün Denizli’ye göç ettiği koşullarda Kınıklı, Servergazi gibi semtleri tercih ettiği, öğrencilerin ve yalnız yaşayan beyaz yakalı göçmenlerin Bağbaşı ve Kınıklıdaki apartlarda yoğunlaştığı görülmektedir. Kentte sayıları giderek artan İran, Suriye, Irak, Afganistan menşeli göçmenler de uluslararası göçmen statüleri nedeniyle tamamen araştırmanın dışında bırakılmıştır. Araştırmanın gerçekleştirildiği mekanlar harita üzerinde izlenebilir.

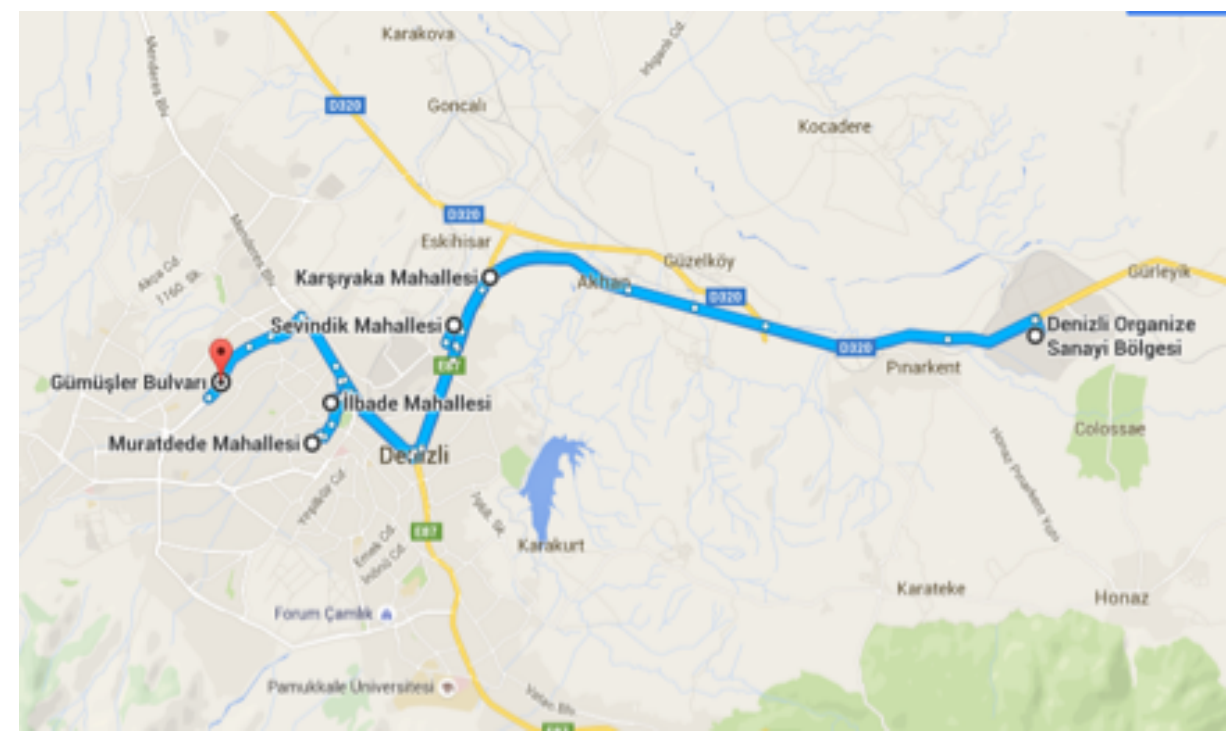

Şekil 1. Denizli'de Göç ve Mekansal Dışlanma Araştırmasının Gerçekleştirildiği Mekanlar 


\section{Araştırma Sonuçları}

Denizli’ye göç edenlerin mekânsal yoğunlaşmasına ilişkin ilk bulgu Denizli'ye yönelen göçün kaynak mekanına coğrafi yakınlık ve hemşerilik ağlarının, hedef mekanın başlıca belirleyicileri olduğudur. Örneğin araştırmanın gerçekleştirildiği İlbade’ye göç yaklaşık 40 yıl önce Denizli ilçe ve köyleri ile Afyon ve Burdur'un köylerinden ekonomik gerekçelerle başlamıştır. Göçmenlerin çoğunluğu erkek aile bireylerinin izleyicisi olarak gelmişlerdir. Gümüşler, Alpaslan ve Esentepe mahalleleri, göçmenlerin kaynak mekanlarına göre ayrılmıştır. Örneğin Alparslan Mahallesi daha çok Denizli ilçeleri ve çevre illerden göç edenlerin yoğunlaştığ 1 bir mahalle iken, Esentepe Mahallesi Muş, Ağrı ve Siirt ilçe ve köylerinden son 10-20 yılda göç edenlere ev sahipliği yapmaktadır. Karşıyaka Bölgesi ise çok daha kozmopolit özellikler taşımaktadır. Burada Bulgaristan'dan, Güneydoğu ve Doğu Anadolu’dan, Afyonkarahisar'ın özellikle Dinar ve Sandıklı gibi yakın ilçelerinden, Burdur'un Yeşilova gibi yakın ilçelerinden göç edenlere, Denizli'nin ilçe ve köylerinden göç edenlerden, çoğunluğu Manisa'dan göç etmiş Romanlara kadar çok sayıda göçmen gruba rastlamak mümkünken, hepsinin ayrı sokaklarda konut edindikleri ve birbirleriyle yoğun bir iletişim kurmadıkları görülmüştür. Araştırmada, göçmenlerin temel refah hizmetlerine erişim olanakları, dışlanmışlık algıları, suça bulaşma ve mekânsal damgalanma deneyimleri ve hemşerilik ve akrabalığa dayalı ilişki ağları mekânsal dışlanma bağlamında irdelenmiştir. Ayrıca Denizli’ye 1990 öncesi göç eden gruplarla 1990 sonrası göç eden grupların sosyal dışlanma/içerilme deneyimlerinin farklılaşıp farklılaşmadığı da sorgulanmıștır.

\section{Mekânsal Dışlanma ve Temel Refah Hizmetlerine Erişim}

Tarihi mezarlığın yanına kurulu olan İlbade ilçesi, kent merkezine yakınlığı ve gecekondu yapmaya uygun arazilere sahip olması nedeniyle birinci kuşak göçmen nüfus tarafından tercih edilmiştir. Bir katılımcı İlbade'yi göç mekanı olarak tercih nedenlerini "Burası hem pazara hem mezara yakın" biçiminde dile getirmiştir. Oldukça eski bir yerleşim yeri olmasına ve merkezi konumuna karşın, halen yol sorunu, hava kirliği, okullardaki düşük eğitim kalitesi, kreş, spor ve rekreasyon alanlarından yoksunluk gibi sorunların devam etmesi, mekânsal dışlanmayı gözler önüne sermektedir. Mahalleye ilk yerleşen birinci kuşak göçmenlerin göç tarihleri 50 yıl öncesine da- yandığı halde, "yoksulluk ve suçla" anılmaya devam etmektedir. Belediyecilik hizmetlerinin gelişmemiş olması göçmenlerin en çok yakındığ 1 sorundur: " $B i$ parkl, şurda gördügün oyun, spor aletlerini ... kaç defa dilekçe verdik şu arkadaşla bak. O kadar imza topladik, ancak bir tane öyle yaptırdık. Yani gerçekten buraya belediyeden kesinlikle hizmet yok." (K7)

Sözü edilen uzun süreli taleplerle yapılan park alanında iki lise öğrencisiyle yapılan görüşmede ise park alanının geceleri güvensiz olmasından ve gece parkta içki içilip bira şişelerinin kırılmasından yakınılmıştır. Ayrıca görüşme yapılan tüm yerleşim alanlarında çöp toplama hizmetleri şikayet konusudur: "Bu tarafta hizmet pasif kalıyor, çöp bile haftada bir kere yapılıyor yada iki kere, ben çamlik bayramyeri tarafindan çalışıım oralarda her gün çöp arabası geçiyor burası dışlanmış gibi” (K1)

"Bu mahalleye var ya belediyeden çöp çöp üstüne yani bi sosyal hizmet gelmedi." (K3)

"Mahallede elektrik yok su yok altyapı saten hiç yok, belediye gelip çöpleri bile almıyo geceleri uyuyamıyoruz kokudan evin içine siniyo koku" (K 21)

Organize Sanayi Bölgesine yakın olan Karşıyaka ve Gümüşler'de hava kirliliği özellikle çocuk sahibi kadın katılımcıların en çok dile getirdikleri sorun alanidir.

Karşıya, Ankara Asfaltı üzerindeki merkezi konumunun da etkisiyle göreli olarak daha gelişmiş, temel hizmetlere ulaşımın daha kolay olduğu bir bölgedir. Ancak Karşıyaka’nın merkezinden uzaklaştıkça, yaşam kalitesinin düştüğünü, belediyecilik hizmetlerinin kötüleştiğini ve mekânsal dışlanmanın gözle görülür bir hal aldığını gözlemledik. Karşıyaka’daki dik yokuşu yukarıya doğru tırmandıkça, dışlanmanın boyutu da artmaktaydı. Örneğin Karşıya sırtlarında konumlanmış olan ve televizyon vericileri nedeniyle antenler olarak adlandırılan Roman mahallesi, düşük konut kalitesi, yoksulluk, refah hizmetlerine erişim sorunları ile dikkat çekmekteydi.

Ekonomik gerekçelerin yanı sıra güvenlik gerekçesiyle zorunlu göç mağdurlarına ev sahipliği yapan Esentepe'de yoksulluğun boyutları çok daha çarpıcrydı. Bu mahallede, 2-3 odalı hanelerde birden fazla ailenin barınması son derece yaygındı. Tek bir gecekondu dairesinde yaşayanların sayısı 18 kişiye kadar 
çıkabilmekteydi. Çoğunlukla gecekonduların çatısız olduğu bu mahallede, gecekonduya kat çıkarak çocuklara yeni ev açma sıklıkla görülmekteydi.

\section{Göçmenlerin Dışlanmışlık Algısı}

Mekânsal ayrışma salt yerli- göçmen nüfus arasında ortaya çımamakta, göçmen nüfusun kendi içinde de ilk göç eden ve sonradan göç eden kuşak arasında, batıdan ve doğudan göç edenler arasında, farklı etnik kökenlere mensup olanlar arasında da ikinci bir ayrışma gerçekleşmektedir. Örneğin Erzurumlu bir erkek katılımcı "Bizi doğudan gelmiş diye küçümsüyolar yolda selam bile vermiyolar yüzümüze bakmiyolar" ( $K$ 21) biçiminde yakınmıştır.

Esentepe'de ağır yoksulluk, temel hizmetlere erişim sorunları, etnik farklılaşma ve özellikle kadınların bir bölümünün Türkçe bilmemesi, katılımcıların önemli bölümünün dışlandıklarını vurgulamalarına yol açmıştır. Kendilerine ayrımcılık yapıldığından, kimsenin onlara yardım etmediğinden, onlarla ilgilenmediğinden, selam vermediğinden, yolda yürürken bile kendilerinin tehdit olarak görüldügünden ve dışlandıklarından şikâyetçi olmaktadırlar. Kendilerine ve bulundukları bölgeye herhangi bir devlet/belediye hizmeti olmadığından altyapı gibi temel sorunların bile bölgeye getirilmediğinden bahsetmişlerdir. Ağr1lı bir kadın katılımcı bu durumu "Bizi kabullenmiyola kimse selam vermiyo hal hatır sormuyo buraya atılmış vaziyette yaşıyoz" biçiminde ifade etmiştir. (K24)

Yapılan görüşmelerde İlbade’de yaşayan katılımcıların ayrımcılığa ve dışlanmaya ilişkin belirgin bir algıları olmadığı saptanmıştır. Bununla birlikte mahallede mekânsal dışlanmayla oluşan içe kapanmadan söz edilebilir. Hemşerilik ağlarının çok güçlü olduğu İlbade'de, söz konusu ilişsi ağlarının dışındaki kişilerin konut edinmesi hoş karşılanmamaktadır:

"Burda kimse kimsenin etlisine sütlüsüne karışmaz bi de bu mahalledekinin hepsi belki 30 yıldan beri burda. Yabancı yok. Yabancı olmadiğı için de herkes birbirisini biliyo...Yabancı olsa muhakkak sıkıntı olur. Mutlaka bi şekilde bişeyler çıka yani. Birkaç defa gelen oldu zaten, hemen gittiler" (K5)

"Yani ben Tavaslilarla evlendim, yani Tavaslilar burda, mahaledekinleri biliriz. Öyle, o kadar çok yok yani, kendi içimizdeyiz biz. Zaten üç kardeşim ben, kardeşlerimle dayılarımın yengelerim derken onlarla zaman geçiriyoz."
Dışlanma algısına en çok sahip olan kesim kadınlar ve Romanlardır. Bununla birlikte Romanlar toplum tarafından eskiye göre daha çok içerildiklerini düşünmektedirler: "Çingen işte bu oynama, küçük çocuklara mesela kızım şunlan oynama bak bu roman, Çingen diye ama şimdi yok. Şimdi bak bunlar Roman sicakkanlidır diyen insanlar çok oluyo."(K37)

Göç sonrası yoksulluk sorunuyla karşı karşıya kalanlar kendilerini daha çok toplumun dişında hissetmektedirler: "Burda çalışmadiğın gün az. Buranın anahtarl, bütün anahtar alp satılan paraya bakıyo. Köy yerinde satar bi şey yaparsin. Ordan biri, komşun dahi bakar sana ama burda maalesef sürüyolar adam." (K29)

Mahallede egemen olan hemşerilik ilişkilerinin dışında bir merkezden, evlilik yoluyla göç eden kadınlar, göçün erken aşamalarında en çok uyum sorunu yaşayanlardır:

"Yabancısın kimseyi tanımıyosun akraban yok gidiyim geliyim dertleşecek kimsen yok, ana baba yok onun için sıkıntı çektik"(K 7)

"Başım sıkınca ailem gelemez ki o yüzden önce komşu gelir" (K 22)

"Tabi, akraba olduktan sonra biri birini gözetiyo gene ama yalnız kaldın mı yabancı gibisin" (K29)

\section{Göç, Mekansal Dışlanma ve Kriminalizasyon}

Büyük kentlerin heterojen ve dezavantajlı grupların yaygın olarak yaşadığı periferik yerleşimlerinde, devlet hakimiyetinin azalması ve suç oranlarının yüksekliğinin yarattığı bir güvensiz ortam hâkimdir. Uyuşturucu kullanımı ve ticareti, dükkanlardan kıyafet ve ayakkabı çalma, konser, maç, sinema, otobüs gibi ücretli alanlara ödeme yapmadan girme, vandalizm (posta kutularını tekmeleme, otobüs duraklarına zarar verme gibi) söz konusu yerleşim yerlerinde özellikle gençlerin bulaştı̆̆ yaygın suçlar arasındadır. Gençlik çă̆ındakilerin bu suçlara yalnızca eğlenmek, otoriteye karşı koymak ya da suç kariyerine adım atarak "önemli" biri haline gelmek için bulaşmaları söz konusu olabilmektedir (Wacquant, 2007, s.207-209).

Araştırma mekanlarımızın tamamında katılımcılar, yaşadıkları yerlerde suça bulaşmanın yüksekliğinin yanı sıra, mahallelerinin suçla anılıyor olmasından 
duydukları rahatsızlığı dile getirmilerdir: "Denizlinin zenginleri gece karanlikta geliyor buraya esrar almaya, o yüzden mahallenin adı çıkmış" "Üst tarafta yol kesme esrar her türlü olaylar oluyor güvenlik yetersiz". (K22)

Katılımcıların önemli bölümü, mahallelerinin suçla damgalanmış olmasının kendilerine ve çocuklarına yönelik toplumsal kalıp yargılar oluşturmasından da yakınmışlardır: "Dışlandığımızı hissediyoruz, buranın adı çıkmıs bir kere".

Periferik yerleşim alanlarında yaşayanları suçluluğa iten etkenler yalnızca kendi iç dinamiklerinden kaynaklanmamakta, toplumun ve kamu otoritelerinin bu tür bölgelere ve orada yaşayanlara verdiği tepkiler, mekânsal damgalanma ve mekânsal dişlanmada etkili olmaktadır (Gökçearslan Çifci, 2008, s. 141). Çok sayıda katılımcı mekânsal damgalanmadan şikayet etmiştir:

"Bize sorduklarında Karşıyaka diyince kötü şeyler oluyormuş orda diyorlar. Orası 'Teksas' gibi diyorlar ama hiç öle değil bir sorunumuz yok, bundan birkaçyıl önce kötüydü, içki içen çoktu cahil çoktu"(K24)

"İlbade, Esentepe dedin mi zaten korkup kaçıyo millet. 'Dinlen dinlen gaç', öyle diyolar. Yani İlbadeli mi tamam dur orda hiç ağzını bile açma ona derler." (K1)

"Karşıyaka Karşıyaka değil Teksas diye bi şarkısı var ya buranın.. Ay nası duruyosunuz orda orası çok fenaymış biz korkuyoruz oraya gitmeye diyenler var" (K27)

Mekânsal dışlanma, kapanma ve mahalle dışındakileri dışlama, yabanciları mahalleye almama, mahalle güvenliğini çete benzeri gruplarla sağlama gibi sonuçlar da doğurabilmektedir. Bir katılımcı bu durumu şöyle ifade etmiştir:

"Mesela Dokuzkavaklar"dan 4, 5 genç gelip burada birisine çatsa buradaki gençler birlik olurlar hemen, kimse kendini ezdirmez burada, buraya gelip kimse bize küfür etse biz dayanamayı, sen burada durmuyorsun neden gelip burayı rahatsız ediyorsun"(K3)

\section{Göçmenlerin İlişki Ağları ve Köyle Olan Bağları}

Göç edilen bölge seçiminde akraba, tanıdık ve hemşerilerin varlığı o bölgeye göçü artırmıştır. Özellikle

3 Dokuzkavaklar da suçla anılan ve göçmenlerin yoğun olarak ikamet ettiği bir yerleşim yeridir. doğudan göç edenler bölge seçiminde tanıdık varlığının en önemli neden olduğunu söylemişlerdir. Doğu ve Güneydoğu Anadolu’dan 1990 sonrası göç edenler kendi aralarında hemşerilik bağlarının çok yüksek olduğunu belirtmişlerdir. Geride herhangi bir mülklerinin ve akrabalarının kalmadığını, bu yüzden geri dönmeyi düşünmediklerini de ifade edenler yoğunluktadır. Ancak güvenliklerinin sağlanması sonucunda geri döneceklerini belirtenler de vardır. Örneğin Siirtli bir katılımcı "Barış olursa belki köyüme dönerim, dönerim de oralar ne haldedir şimdik hiç bilmiyim" (K19) sözleriyle geri dönüş umudunu dile getirmiştir.

Denizli çevresinden göç edenler ise geride kalanlarla arada sırada görüşmelerine ve bazıları memleketlerinde mülk sahibi olmalarına rağmen artık kentli oldukları için geri dönemeyeceklerini belirtmişleridir: "Köyde 2 göz ev var kiraya verdük, aylık 75 tl geliyo, onunla yicek içcek aliyoz mutfak masraflarının birazını karşıliyo" (K6) .

Denizli ilçelerinden göç edenler memleketleri ile bağlarını tamamen koparmamışlardır. Bazı katılımcılar az da olsa akrabaları tarafından köylerinde yetişen gıda ürünlerinden yararlandıklarını ya da köylerinde tarlası olanlar kendileri ekmeye devam ettiklerini, ürün vakti geldiğinde az miktarda da olsa gida desteği olduğunu belirtmiştir. Köydeki tanıdıkları ile görüştüklerini ancak maddi bir yardım almadıklarını ifade etmişlerdir.

Göç ağlarının iki yönlü bir etkisi bulunmaktadır. Bir yandan hemşeri ve akrabalık bağları yoluyla dayanışmanın artışı ile kente uyum, iş ve konut edinme kolaylaşmaktadır. Öte yandan özellikle kadınlar üzerinde denetim artmaktadır. Kadın katılımcılar bu durumu şu sözlerle ifade etmişlerdir:

"Kalabalı̆g severim avantajlı ama izin vermiyolar $\mathrm{d}_{1-}$ şarı gitmeme o yüzden dezavantajlı”(K23)

"Burası şey nası diyim çarşıda yani bin kaşık kişi yaşadĭ̆ı için rahat gezebiliyorsun. Burda tabi herkes herkesi tanıdiğı için biraz daha sorun olabiliyo tabi, belki benim açımdan." (K2)

\section{Eski Göçmen- Yeni Göçmen Ayrımı}

Denizli’ye 1990 öncesi göç edenlerle 1990 sonrası göç edenlerin kente uyum ve dişlanma pratikleri açısından dikkat çekici bir fark ortaya çıkmaktadır. 
1990 öncesinde Denizli’ye göç edenlerin \% 19'u hemen hemen her zaman, \% 62'si zaman zaman kent merkezine gittiğini belirtirken; \% 19'u hemen hemen hiçbir zaman gitmediğini belirtmiştir. 1990 ve sonrasında göç edenlerin \% 6'sı hemen hemen her zaman, \% 68'i zaman zaman kent merkezine giderken, $\%$ 26'sı hemen hemen hiçbir zaman kent merkezine gitmemektedir. Bir başka ifadeyle Denizli'de yaşanan süre arttıkça kent merkezine gitme sıklığ 1 artmaktadır (Uslu, 2012, s.82). 1990 öncesinde Denizli'ye göç edenlerin \% 1'i yoksul olduğu için, \% 16'sı doğudan geldiği için dışlandığını belirtirken, tamamına yakını ise (\% 83) dışlandığını düşünmediğini belirtmiştir. 1990 ve sonrasinda gelenlerin ise \% 10'u yoksul olduğu için, \% 32'si doğudan geldiği için dışlandığını ifade etmiş, \% 58'i dışlanmadığını söylemiştir. 1990 öncesinde Denizli'ye göç edenlerin yalnızca \%'2 sine göre yoksulluğun nedeni göç etmiş olmakken 1990 ve sonrasında göç edenlerin \% 20'sine göre göç etmiş olmaktır. Üstelik aynı araştırma yoksulluktan kurtulacağına inananların \% 67,8'inin 1990 öncesinde, \% 32,2'sinin 1990 ve sonrasında göç ettiğini ortaya koymuştur. Denizli'ye 1990 'lı ve 2000 'li yıllarda göç edenler sosyal dişlanma sorunuyla daha çok yüz yüze kalmış, daha çok ikincil işgücü piyasasında kendisine yer bulabilmiş ve daha çok ekonomik sorunla karșılaşmıştır. Bu nedenle 1990 ve sonrasında göç edenlerin \%48'i yardım almaktadır. (Uslu, 2012, s.83-85)

Uslu (2012)'nin ortaya koyduğu gibi 1990'lar ve öncesinde göç edenler, geçen ylllar içinde göreli olarak daha yüksek gelir olanaklarına kavuşmuşlardır. Bir katılımcı sahip olduğu mal varlığının değişim seyrini çarpıcı biçimde şöyle aktarmıştır: "İlk geldik motokuzimiz vardl, sonra Anadol aldik, sonra Fordumuz kamyonumuz oldu. Kamyonumuz varken birinci katı yaptık, sonra diğer katı yaptık. Artık evde kiracımız var." (K4)

Çok sayıda katılımcı tarafından 1980'lerin ikinci yarisından itibaren küresel sermayeyle eklemlenerek büyüyen tekstil sektörünün göçmen işgücünü emme kapasitesini zaman içinde kaybetmesi çok sayıda katılımcı tarafından "O zamanlar tekstil vardı!" biçiminde ifade edilmiştir.

Erken aşamalarda göç edenler, ekonomik kriz sonrası işsizliğin baş göstermesine, yaşam koşullarının zorlaşmasına vurgu yapmışlardır. 1990 sonrası göç edenler ekonomik koşullarından memnun değildir: Katılımcıların "Burda yaşarız diye geldik, burda te- melli rezil olduk", "Bir şeye yaramadı orda ne iş yapıyorsak burada da öle aynı" "Yeni düğ̈̈n yaptık, ev kira, dükkan kira, borç çok bu aralar çok sıkıntıdayık" gibi ifadeleri göçün ekonomik koşullarını düzeltici bir etki yapmadığını ortaya koymaktadır.

1960 'lı ylllardan itibaren vasıfsız göçmenler kendi hesabına ticari faaliyetler veya tekstil iş̧̧iliği gibi faaliyetlerle işgücü piyasasına görece kolayca katılabilirken, 1990'lardan sonra vasıfsız işgücünün işgücü piyasasına entegrasyonu zorlaşmış ve ancak ikincil işgücü piyasasına girebilmeleri mümkün olmuştur. 2000 'li yıllarda Hakkari'den göç eden bir katılımcı bu durumu şu sözlerle dillendirmiştir: "Saten ilkokul mezunuyum bi yeteneğim de yok kim, nerde, ne işverecek ki yapıyım o yüzden hamallik yapıyom. Haftanın belli günleri hale gidiyom ekmek parası kazancak başka iş yok".(K37)

Vasıflı veya yarı vasıflı katılımcılar, yakın dönemde göç etseler dahi koşullarının daha iyi olduğunu vurgulamışlardır: "Ben Uşak'ta tekstilde çalışıodum, makine biliyom, 2008 krizi bizim firmayı da vurunca Denizliye taşınmaya karar verdim, geldiğim gibi de iş buldum" (K28)

"Güney'de berberdim ben, hafta da iki bilemedin üç gün iş oluyodu şimdik burda her gün iş oluyo, iki klzım var üniversite de onları okutcak kadar kazanıyoz" (K13)

Araştırmanın gerçekleştirildiği mahallelerde, kadınların yaygın olarak tekstil fabrikalarında işçi oldukları veya ev eksenli olarak tekstil ürünleri ve baharat üretiminde çalıştıkları gözlenmiştir. Erkeklerse yaygın olarak inşaat, mermer, tekstil sektörlerinde çalışmakta veya pazarcılık, hurdacılık gibi işler yapmaktadırlar. Özellikle Roman mahallelerinde kız çocuklarının küçük yaşta okuldan çekilmesi ve işgücü piyasasına girmesinin yaygın olduğu görülmüştür. Bir kadın katılımcı kız çocukların okutulmaması gerekçesini "Nasıl olsa evlenince çalı̧mayacak, bi de akrabalara veriyolar" sözleriyle açıklamıştır. Yoksulluk da diğer bir önemli gerekçe olarak dile getirilmiştir: "Bak şeye hiç okumadı tekstile giden kızım. 25 gün gitti ondan sonra okutamadim. Gönderemedim, kimisi gönderemiyo" (K 36)

İşücü piyasasındaki göçmen genç kızlar evlenince, eşleri veya eşlerinin ailesi tarafından işgücü piyasasından çekilmeleri talep edilebilmektedir. Bu duru- 
mun gerekçesini bir erkek katılımcı "(Bir evde karı kocanın) ikisi de çalışıyo. İkisi de çalıştı mı bi avradın içerde tadı olmaz." sözleriyle açıklamıştır. Öte yandan göçmen kadınların önemli bir bölümünün çocuk bakım yükü nedeniyle ev eksenli çalışmayı tercih ettiği de görülmüştür.

\section{Sonuç}

Araştırma alanımızı oluşturan Gümüşler, Karşıyaka, lbade, Esentepe, Alparslan mahalleleri göç ile oluşmuş ve göçmenlerin mekansal dışlanmasına bir örnek oluşturacak niteliklere sahip yerleşim yerleridir. Bölgedeki göçmen nüfusun işgücü piyasasındaki düzgün işlere erişim düzeylerini yanı sıra, temel refah ve altyapı hizmetlerine erişimlerinin de yetersiz olduğu görülmüştür. Bununla birlikte göçmenler arasında göç dönemi, göçe kaynaklık eden bölge ve etnisiteye dayalı ikinci bir ayrışma yaşandığı görülmüştür. Yakın dönemde göç edenler, erken dönemde göç edenlere göre, doğudan göç edenler batıdan göç edenlere göre, Denizli dışından göç edenler, Denizli'nin ilçelerinden göç edenlere göre temel toplumsal ve insani ihtiyaçlarını daha zor karşılamakta ve kentsel hizmetlerle kentin sosyo-kültürel olanaklarına daha az erişebilmektedirler. Denizli ilçelerinden, özellikle de 1990 öncesi dönemde göç edenlerin maddi durumları daha iyi düzeyde olmakla birlikte konutları daha büyük, yaşam şartları daha iyidir. 1990 sonrası, başka illerden gelen ve işgücü piyasasında geçerli vasıflarla donanmamış olanlar birbirine sıkışık gecekondu tipi evlerde daha çok kişiyle birlikte yaşamaktadır ve gelir düzeyleri düşüktür. Söz konusu mekânsal adaletsizliğin yanı sıra, mekânsal damgalanma ve kriminalizasyon bu mahallelerde dikkat çeken başka bir sorun alanıdır. Bu mahallelerde suça bulaşma daha yoğun olduğu gibi, bu yerleşim alanları kentin diğer sakinleri tarafından da "suç"la anılmaktadır.

\section{Kaynakça}

Adaman, F., Keyder, Ç. (2006). Türkiye’de Büyük Kentlerde Gecekondu ve Çöküntü Mahallelerinde Yaşanan Yoksulluk ve Sosyal Dışlanma, Avrupa Birliği için Rapor erişim. http://ec.europa.eu/employment_social/social_inclusion/docs/2006/study_turkey_tr.pdf.

Akın, O. (2012). İstanbul Kentinin Değişim Öyküsü. Mimarist, 12(45), 46-59.
Atılgan, T., Şen, A. (2006) Tekstil Ve Hazır Giyim Sektöründe 01 Ocak 2005 Tarihinden İtibaren Uygulanmaya Başlayan Korunma Önlemleri Ve Türkiye (Bölüm 2).Tekstil ve Konfeksiyon, 2006 (4), 220224.

Berker, A. (2011). Labor-Market Consequences of Internal Migration in Turkey. Economic Development and Cultural Change, 60(1),197-239.

Buğra, A. (2008). Kapitalizm, Yoksulluk ve Türkiye’de Sosyal Politika, İstanbul: İletişim.

Cook, S. (2015). Rural-Urban Migration and Social Exclusion Among Cambodian Youth. Utrecht University, Faculty of Geosciences Master Thesis International Development Studies

Dikeç, M. (2001). Justice and The Spatial Imagination. Environment and Planning, 33, 1785- 1805.

Uslu, L. (2012). Göçmenlerde Yoksulluk Yansımaları: Denizli Örneği (Doktora Tezi), Denizli: Pamukkale Üniversitesi.

Gökçearslan Çifci, E. (2008). Kapkaç Suçundan Hüküm Giyenlerin, Sosyo-Demografiközellikleri, Sosyal Dişlanma Süreçleri, Suç ve Diğer Sapmadavranışlar Açısından İncelenmesi (Doktora Tezi), Ankara: Hacettepe Üniversitesi.

Güzel, S. (2013). Göçmen Çocuklar ve Denizlide Yaşam Koşulları. Hacettepe Üniversitesi Sosyolojik Araştırmalar Dergisi,51,1-36, http://www.sdergi. hacettepe.edu.tr/makaleleler_cerceve.htm

Işık, O. (1996). Denizli ve İstanbul Dersleri. Birikim. 86-87,42-48.

Işık, O., Pınarcıoğlu, M. (2003). Nöbetleşe Yoksulluk. İstanbul: İletişim.

İçduygu, A., Sirkeci, İ.(1999) Cumhuriyet Dönemi Türkiye'sinde Göç Hareketleri, Oya Baydar n(Ed.). 75 Yilda Köylerden Şehirlere içinde. İstanbul: Tarih Vakfi.

Kalkınma Bakanlığı (2014). Onuncu Kalkınma Planı Göç Özel İhtisas Komisyonu Raporu. Ankara: Kalkınma Bakanlığı. 
Kara, H. (2010). Denizli Şehrinde Gecekondulaşmanın Önlenmesi ve Toplu Konutlar. Eastern Geographical Review, 23, 103- 118.

Karaçay- Çakmak, H., Erden, L. (2005). Yeni Sanayi Odakları ve Sanayinin Yeni Mekan Arayışları: Denizli ve Gaziantep Örneği. C.Ü. İktisadi ve İdari Bilimler Dergisi, 6(1), 111-129.

Kaya, A. ( 2009) Türkiye’de İç Göçler Bütünleşme mi Geri Dönüş mü?. İstanbul: İstanbul Bilgi Üniversitesi.

Kaygalak, S. (2001). Yeni Kentsel Yoksulluk, Göç ve Yoksulluğun Mekansal Yoğunlaşmasi: Mersin/Demirtaş Mahallesi Örneği. Praksis, 2, 124- 72.

Madanipour, A. (2016). Social Exclusion and Space. The City Reader (Ed. R. T. LeGates, F. Stout), London: Routlege.

Mangır, F., Ay, A. (2009) Türkiye'de Tekstil-Hazır Giyim Sektörleri ve Rekabet Gücü, Selçuk Üniversitesi Sosyal Bilimler MYO Dergisi, 12 (1-2), 175-190.

Özbay, F., Yücel, B. (2001). Türkiye’de Göç Hareketleri, Devlet Politikaları ve Demografik Yapı. Ankara: Hacettepe Nüfus Etütleri Enstitüsü.
Sapancalı, F.(2003). Sosyal Dışlanma. İzmir: Dokuz Eylül Üniversitesi İktisadi ve İdari Bilimler Fakültesi.

Tekeli, İ. (2008). Göçve Ötesi. İstanbul: Tarih Vakfı.

Torlak, S. E.- Polat, F. (2006). Kentleşme Sürecinde Kimlik Farklılaşması Açısından Denizlide İki Mahallenin Karşılaştırmalı Analizi. Gazi Üniversitesi İ̈BF Dergisi, 8 (2), 167-186.

Uslu, L. (2012). Göçmenlerde Yoksulluk Yansımaları: Denizli Örneği (Yüksek Lisans Tezi). Denizli: Pamukkale Üniversitesi.

Yalçın, C. (2004). Göç Sosyolojisi. Ankara: Anı.

Zohir, S. vd. (2008). Exclusion and Poverty: An Analytical Approach for Understanding Exclusion and Assessing Programmes Targeting the Very Poor in Bangladesh. Dhaka: BRAC/ Economic Research Group.

http://www.tuik.gov.tr/VeriBilgi.do?alt_ id $=1067$ 